Bulletin of the Natural History Museum, 2016, 9: 95-105.

Received 0111 2016; Accepted 21 Dec 2016.

doi:10.5937/hnhmb1609095P

UDC: 595.754(497)

Original scientific paper

\title{
DIMORPHOCORIS SAULI (HETEROPTERA: MIRIDAE), A NEW SPECIES FOR THE FAUNAS OF SERBIA AND MONTENEGRO
}

\section{LJILJANA PROTIĆ}

Natural History Museum, 11000 Belgrade, Serbia, e-mail: 1jilja.protic@gmail.com

Dimorphocoris saulii Wagner is a new species for the faunas of Serbia and Montenegro as well as a new genus for the fauna of Serbia. Genus Dimorphocoris is represented in Balkan Peninsula with nine species: D. beieri Wagner, D. debilis debilis (Reuter), D. fuscus Joakimov, D. gracilis (Rambur), D. lateralis Reuter, D. sari Linnavuori, D. sauli Wagner, D. schmidti (Fieber) and D. tristis (Fieber). Within the Balkan Peninsula they inhabit Mts Dinarides (Montenegro, Croatia, Slovenia, Serbia), Mts Rhodope (Bulgaria), Mts Pindus (Greece) and some Mediterranean islands.

Key words: Dimorphocoris, Heteroptera, Serbia, Montenegro, Balkan Peninsula

\section{INTRODUCTION}

The genus Dimorphocoris Reuter is represented in Palearctic with 56 species (Aukema \& Rieger, 1999). It is distributed from the Mediterranean region to Central Asia, as well as in Eastern Africa and at Sakhalin Island 
in the North Pacific Ocean (Kerzhner 1970, Wagner 1973, Ehanno 1993, Linnavuori 1992, Ehanno \& Ribes 1994, Tatarnic \& Cassis 2012). This genus includes two main groups, named: "gracilis" and "lateralis" (Tatarnic \& Cassis 2012). In the "gracilis" group, males are macropterous while females are brachypterous, while in the "lateralis" group both sexes are brachypterous.

Both groups are present in Europe and Balkan Peninsula. According to the Catalogue of Heteroptera of Palaearctic [CHP] (Aukema \& Rieger 1999) 41 species of the genus Dimorphocoris are known for the European fauna. After that publication one more species, D. poggi, was also described (Carapeza 2002).

According to the referenced studies nine species are recorded for the Balkan Peninsula and faunas of Bulgaria, Montenegro, Greece, Croatia and Slovenia:

Dimorphocoris beieri Wagner, 1965

Type locality Montenegro: Durmitor $2400 \mathrm{~m}$ a.s.l (Wagner 1965b, Tamanini 1972, Protić et al. 1990, Ehanno 1997); Durmitor leg. Penther (AMNH PBI00183810).

CHP EU: Montenegro (Aukema \& Rieger 1999).

Dimorphocoris debilis debilis (Reuter, 1880)

Type locality Greece: Attica Dr. Kreuper "specimena non-nulla legit" (Reuter 1880, 1890); Lindberg (1956); Wagner (1965b); Ehano (1993).

CHP EU: France, Greece, Italy (Sicily), Spain, Turkey (European part) (Aukema \& Rieger 1999).

Dimorphocoris fuscus Joakimov, 1909

[= Dimorphocoris riabauti Wagner, 1954]

Type locality Bulgaria: Vitosha, Crni Vrh $2285 \mathrm{~m}$ a.s.l. August $1^{\text {st }}$, 1905; Rila Mt, Musala 2925 m a.s.l. August 1 $1^{\text {st }}$, 1906. "Habitat in gramine" (Joakimov 1909); Wagner (1954); Wagner \& Weber (1964); Vitosha, Rila (Josifov 1961); Pirin "Bajuvi Dupki" 2100 m a.s.l. September 14 ${ }^{\text {th }}$, 1987. (Josifov 1990); Ehanno (1997); Vitosha, Rila, Pirin Mts (Josifov \& Simov 2006).

CHP EU: Andora, Bulgaria, France, Spain (Aukema \& Rieger 1999).

Dimorphocoris gracilis (Rambur, 1839)

[ $=$ Phytocoris gracilis Rambur 1839]

[=Orthocephalus signatus Fieber, 1861; Reuter (1890)]

Type locality Spain: Granada (Rambur 1839). 
Croatia: Solin July $28^{\text {th }}$, 1954. leg. H. Eckerlein. (Novak \& Wagner 1955); Lindberg (1956); Seidensticker (1964); Ehanno \& Ribes (1994); Ehanno (1997).

Note: Mr. Eckerlein from Coburg was collecting in June and July in Dalmatia, mostly in area between Podstrana and Grljevac, near Split.

CHP EU: Croatia, France, Portugal, Spain (Aukema \& Rieger 1999).

Dimorphocoris lateralis Reuter, 1901

Type locality Greece: Chania [Canea] "Hab. locis aridis in insula Creta (Canea! m. martis), leg. Prof. J. Sahlberg" (Reuter 1901); Crete (Lindberg 1956, Wagner 1965a, Eckerlain \& Wagner 1969); Crete, Elaunda b. Aghios Nikolaos on Sarcopoterium spinosum (Heiss 1984); Crete, Canea: Naxos, Chora; Kos, Kardamena; Rhodos, Petaloudes, Kalathos - Asklipio, Santorin (Linnavuori 1992); Ehanno \& Ribes (1994).

CHP EU: Greece (Aukema \& Rieger 1999).

Note: Johan Reinhold Sahlberg (1845-1920) was a Finnish entomologist (specialized in Coleoptera and Auchenorrhyncha). He made expeditions to many parts of Finland, to Russian (Karelia, Siberia), the Mediterranean area, and to Central Asia.

Dimorphocoris sari Linnavuori, 1992

Type locality Greece: Mt. Taygetos 1900m a.s.1. on Peloponnese, "on grasses in a luxuriant moist meadow in the coniferous zone" (Linnavuori 1992).

CHP EU: Greece (Aukema \& Rieger 1999).

Dimorphocoris sauli Wagner, 1965 (Figs 1-2)

Type locality Italy (actually Slovenia): Mt. Auremiano June 1938. leg. L. Sauli (AMNH PBI00183825) (Wagner 1965a);

Slovenia: Karst: Vremščica [Illyria, Mt. Auremiano] (Wagner 1965a); Tamanini (1982); Gogala, M. (1992); Gogala, A. (1994, 2008).

CHP EU: Slovenia (Aukema \& Rieger 1999).

Note: Luciano Sauli (1894-1985) from Trieste was a railway employee who collected both Heteroptera and Homoptera.

Dimorphocoris schmidti (Fieber, 1858)

[=Orthocephalus schmidtii Fieber, 1858]

Type locality Slovenia: Krain leg. Ferdinand Schmidt (Fieber 1858); "Carniolia" leg. F. Schmidt (Gogala \& Moder 1960); Kamniško-Savinjske Alps, Karavanke (Gogala \& Gogala 1986, Gogala, M. 1992, Gogala, A. 1994). Gogala (1992) believed that Schmidt collected this species 
at the locality Dolga Njiva near Krvavec in the Kamniško-Savinjske Alps, where it was rediscovered many years after Schmidt's time.

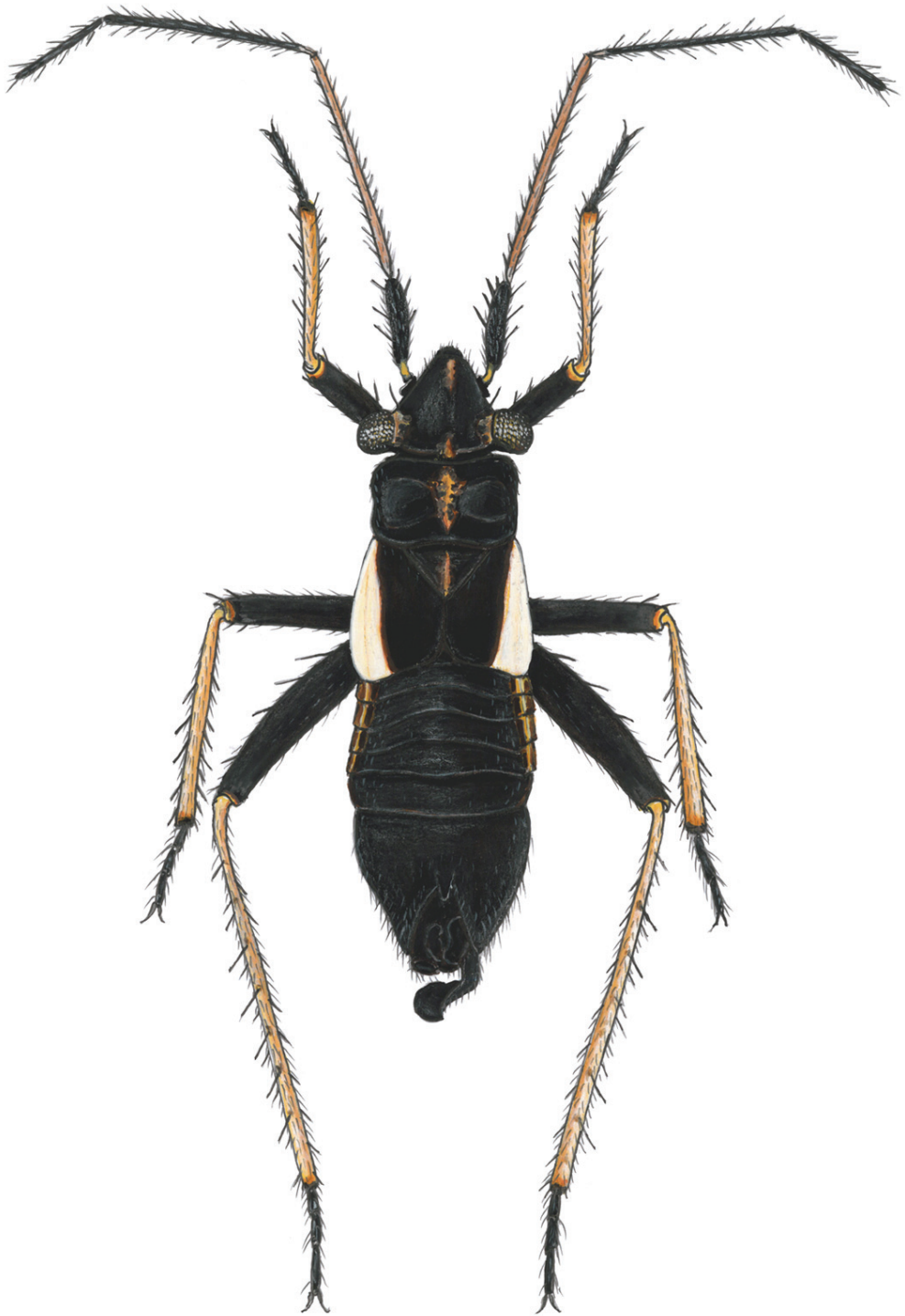

Fig. 1. Dimorphocoris sauli Wagner, male (Drawing by: Aleksandar Stojanović).

CHP EU: Austria, Slovakia, Slovenia (Aukema \& Rieger 1999).

Note: Ferdinand Jožef Schmidt (1791-1878) was a merchant and a naturalist. He was born in Sopron (Hungary). He worked for a short time in Vienna and for the longest period of time in Ljubljana (Slovenia) [Laibach, Krain], until his death. 


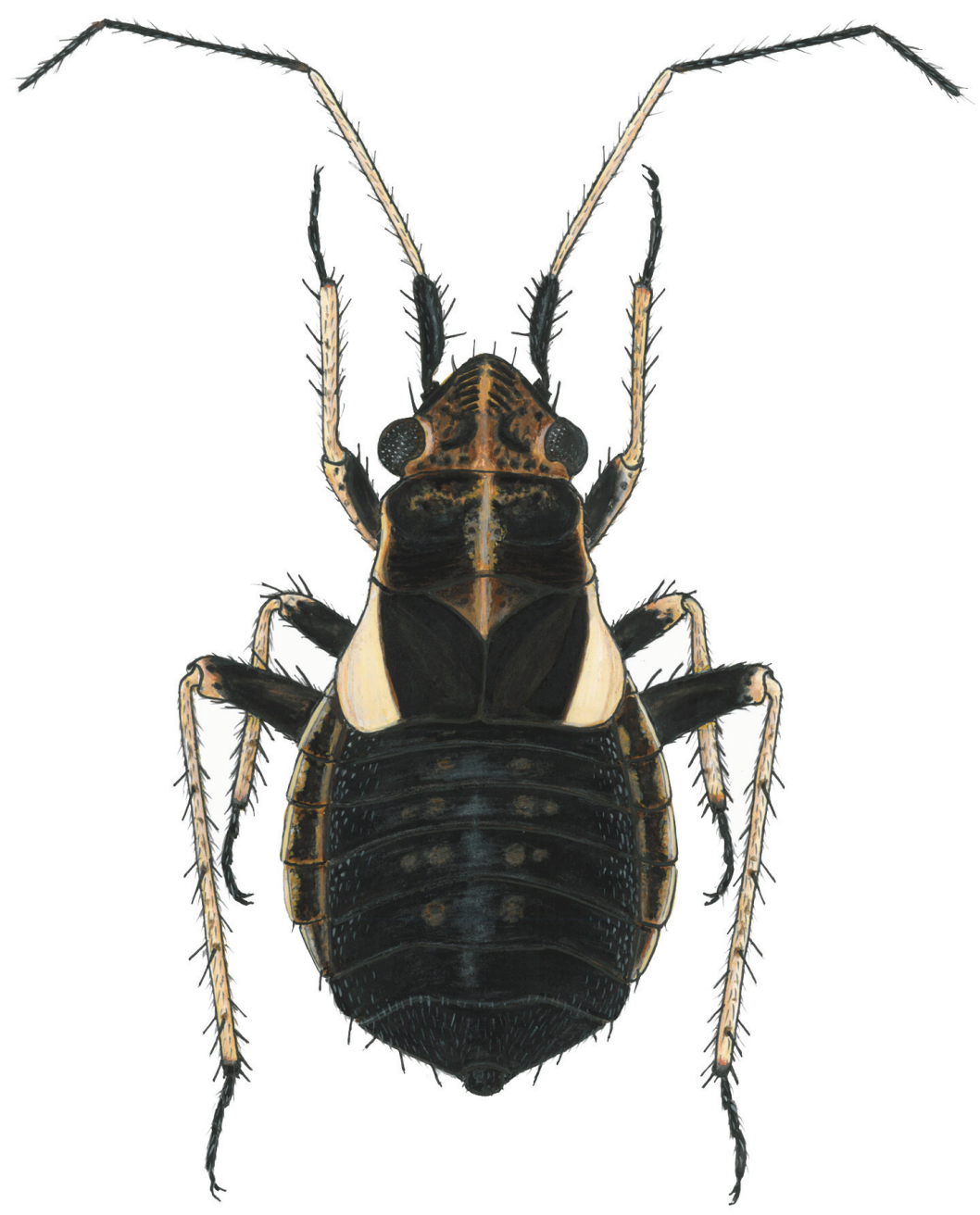

Fig. 2. Dimorphocoris sauli Wagner, female (Drawing by: Aleksandar Stojanović).

Dimorphocoris tristis (Fieber, 1861)

Spain Type locality Spain: Granada (Fieber 1861); Reuter (1890).

Greece: Lindberg (1956); Seidenstficker (1957), on flowers of Anthemis on a sand bank; Wagner (1965, 1973); Linnavuori (1992); Ehanno \& Ribes (1994); Crete: Episkopi (Carapezza 1998).

CHP EU: Greece, Portugal, Spain, Turkey (European part) (Aukema \& Rieger 1999).

This genus was previously unknown from Serbia while endemic $D$. beieri was the only registered species for the fauna of Montenegro. In this paper $D$. sauli is recorded for faunas of Serbia and Montenegro for the first time. 


\section{MATERIAL AND METHODS}

Nomenclature of species is given according to Catalogue of the Heteroptera of the Palaearctic Region (Aukema \& Rieger 1999).

Specimens of $D$. sauli from Serbia and Montenegro are stored in the Entomological Collection of the Natural History Museum in Belgrade.

\section{RESULTS}

Dimorphocoris saulii was described from Italy (actually Slovenia), Mt. Auremiano (Wagner 1969). The second record of the species comes from the same mountain in Slovenia at Mt. Vremščica [Mt. Auremiano] (Gogala, M. 1992, Gogala, A. 1994). This paper presents two new localities in Balkan Peninsula where D. sauli was collected:

D. sauli - new records:

- Serbia: Mt. Stolovi, the mountain ridge Ravni Sto, 960-1080 a.s.1.. $11 \mathrm{~m}, 13 \mathrm{f}$., June $22^{\text {nd }}-23^{\text {rd }}, 2014$. legs. A. Stojanović and Miroslav Jovanović. New genus for the fauna of Serbia.

- Montenegro: Mt. Durmitor, Sušičko Lake. 1f., July 22nd, 1981. leg. Lj. Janković New species for the fauna of Montenegro.

D. sauli belong to the "lateralis" group and both sexes are brachypterous and similar dimensions, between $3 \mathrm{~mm}$ (male) and $3.0-3.4 \mathrm{~mm}$ (female).

The species are phytophagous, with many found on grasses. The majority of host records coming from the family Poaceae. The records from Serbia and Montenegro were collected in mountain meadow associations.

\section{DISCUSSION AND CONCLUSIONS}

So far mentioned new localities of $D$. saulii belong to Mts Dinarides young fold-type mountains of the same type as Alps, Apennines and Pyrenees, bordering Julian Alps at the north and Šara-Pind mountain chain at the southeast. The longitudinal and transverse dislocation lines divide the Dinarides into several units. Mt. Stolovi belongs to Šumadija mountains of the Kopaonik group (Stolovi, Željin, Goč). Ravni Sto (Fig. 3) in Central Serbia is a mountain ridge leading from peak Orlovac (938 a.s.1.) toward the Usovica ridge and further toward the highest peak of Mt. Stolovi Kamarište (1375 a.s.1.). The altitude of this ridge ranged from $960 \mathrm{~m}$ to about $1080 \mathrm{~m}$ above sea level, but $D$. saulii were present everywhere. Ravni Sto is one long unbroken meadow-pasture along the ridge, with a dirt road cutting through it at the middle, while the slopes at the sides of the 
ridge are covered in sparse mixed forest struggling for survival in these conditions. The real scope of its range will be subject of further studies, but it is important to note that this species was not recorded in the same interval of time at nearby Mt. Goč, which has similar geological substrate and similar meadow-type plant association.

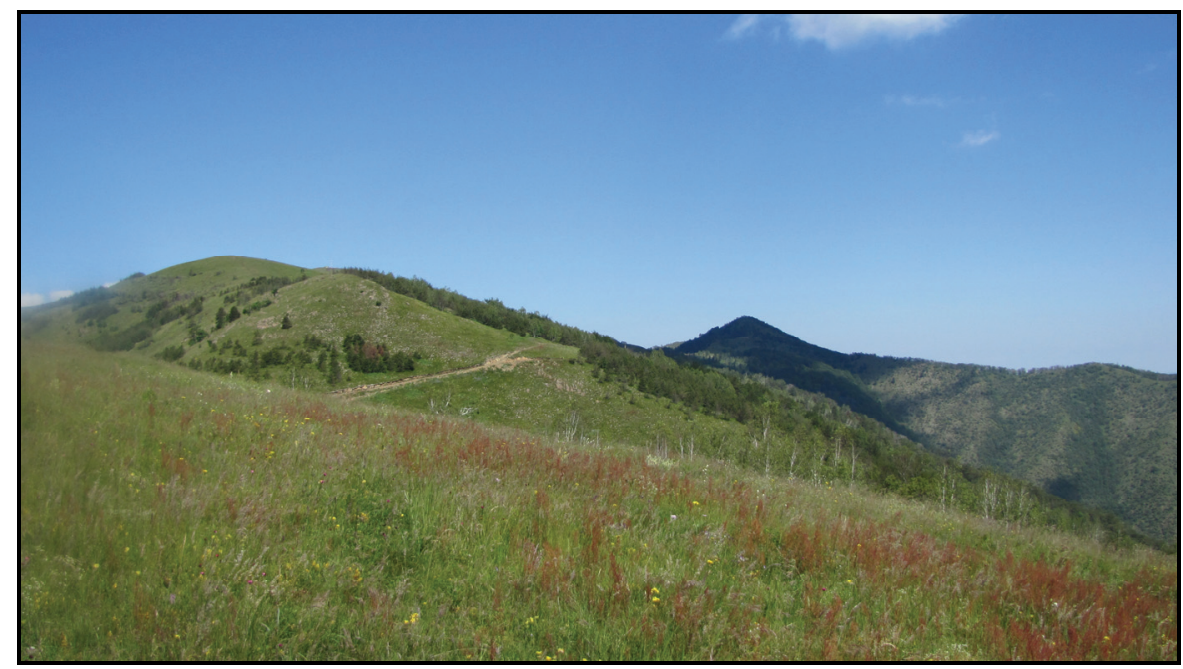

Fig. 3. - Mt. Stolovi, ridge Ravni Sto, 960-1080 m a.s.l. Habitat of Dimor phocoris sauli Wagner (Photo: Miroslav Jovanović).

Canyon of river Sušica in Montenegro is situated on the western slopes of Mt. Durmitor and is $14 \mathrm{~km}$ long. The source of river Sušica is at about $1300 \mathrm{~m}$ a.s.l, and its confluence into river Tara is at $512 \mathrm{~m}$ a.s.l. It is also an underground river for one part of its flow. Three kilometres downstream from the source, the river forms Sušičko Lake at the altitude of $1140 \mathrm{~m}$. This lake is present only from early spring to June, and its greatest depth is about $5 \mathrm{~m}$. Its limestone bed includes several sinkholes through which it loses water. At the season when snow is melting in the surrounding mountains, the lake is filled with water, while later it dries out and in the summer it turns into a meadow valley of extraordinary beauty. Canyon of Sušica and Sušičko Lake are characterized by valley climate, which is a transition between temperate-continental and mountain climates, and these areas are protected from large-scale wind movements. Therefore summers and winters are warmer than in the surrounding areas. As a consequence of all geomorphological and climate conditions, canyon of Sušica is a habitat for many relict species.

In the Balkan Peninsula, species from genus Dimorphocoris inhabit meadow associations in mountains (at altitudes of $1000 \mathrm{~m}$ above sea level 
and above) but also some sandy coastal habitats in Greece and Dalmatia. In late Tertiary, many species of genus Dimorphocoris have retreated to higher altitudes and remained to this day as Tertiary relicts (Josifov \& Simov 2006).

Dimorphocoris beieri was recorded only in Montenegro at Mt. Durmitor. Wagner (1976) described D. beieri after male specimens. In later research of entomofauna of Durmitor macropterous female was also collected and described (Protić et al. 1990). One specimens of D. beieri, collected by Penther, is stored at the American Museum of Natural History in New York (Toby Schuh - Discover Life AMNH PBI00183810).

Dimorphocoris fuscus was described by Joakimov (1909) and until 1964 it was considered endemic to Bulgaria, as it was recorded only on mountains Vitosha, Rila and Pirin. This species was recorded at new localities in Asia during the research of fauna of Mongolia (Kerzhner 1964, 1970) and later also of Tuva in Siberia (Vinokurov \& Kanyukova 1995). Ehanno (1997) performed a review on species $D$. ribauti, concluding that it was actually a synonym for $D$. fuscus. Therefore the range of $D$. fuscus is spreading westward from Bulgaria into Spain, France and Andora (localities where $D$. ribauti was recorded). All these records indicate disjunctive character of range and wide distribution of $D$. fuscus in the Palaearctic.

Species recorded in Europe are mostly concentrated in France (19) and Iberian (12), Italian (10) and Balkan Peninsula (9) (Aukema \& Rieger 1999, Carapeza 2002). They share their predisposition for fold-type mountains formed in Mesozoic. They are generally endemic-relict species with disjunctive ranges in high mountains of Europe, Asia, northern Africa or the coastal zone of Mediterranean. This hypothesis is supported by the geological past of the present range of genus Dimorphocoris. The younger fold mountains in Europe (Alps, Pyrenees, Apennines, Dinarides) were formed in Mesozoic and Tertiary. In Europe, the Alps were in the centre of folding activity. Their northern limestone chains are connected to the Carpathians, which are in turn connected to Balkan and Pontian mountains. The southern limestone chains are connected to the Dinarides and Taurus in Asia Minor. Toward the southwest the Alps are connected to the Pyrenees and toward the south to the Apennines. The mountain massif Atlas in Africa is connected to the Alps through Baetic Cordillera and the Balearics. Yayla Mountains at the Crimea are connected to the Caucasus massif and side branches of Balkans.

Ranges of Dimorphocoris species are mostly small, as among the 42 species recorded in Europe and 30 were recorded only in a single country. D. lateralis is present only in Greece, D. sauli in the Balkan Peninsula, and $D$. schmidtii only in the Alps. Only $D$. debilis was recorded in three large European peninsulas (Italian, Balkan, Iberian) while D. tristis was recorded at Iberian Peninsula and in Greece. 


\section{Acknowledgements}

The author is grateful to Aleksandar Stojanović and Miroslav Jovanović (Natural History Museum in Belgrade) for specimens of Dimorphoocris sauli Wagner collected at Mt. Stolovi and illustrations in this paper, and to Franco Faraci (Italy), Meral Fent (Turkey), Hannes Günther (Germany) and Nikolay Simov (Bulgaria) for help with obtaining literature.

\section{REFERENCES}

Aukema, B. \& Rieger, Ch. (1999): Catalogue of the Heteroptera of the Palaearctic Region 3. Netherland Entomological Society, Amsterdam, 577 pp.

Carapezza, A. (1998): New species and new records of Heteroptera from Cyprus (Insecta). - Atti dell'Accademia Roveretana degli Agiati Ser. VII 8(B): 29-40.

Carapezza A. (2002): Dimorphocoris (s. str.) poggii n. sp., nuovo miride delle Alpi Liguri (Heteroptera Miridae). - Annali del Museo Civico di Storia Naturali “Giacomo Doria" 94: 473-483.

Eckerlein, H., Wagner, E. (1969): Die Heteropterenfauna Libyens. - Acta entomologica musei Nationalis Pragae 38: 155-194.

Ehanno B. (1993): Compléments à la faune de France (et pays voisins) des Hétéroptères Miridae Hahn, 1831. V - des espèces du genre Dimorphocoris Reuter, 1891 (Halticinae, Halticini, Laboparia) 1 - espèces des Alpes (France, Autriche, Italie), des Apennins (Italie) et du domaine Meditérranéen: additions aux donées acquises et descriptions d'espèces nouvelles. - Bulletin de la Société Scientifique de Bretagne 63 (1992): 5-187.

Ehanno, B., Ribes, J. (1994): Compléments à la faune de France et de pays voisins: Espagne (Cátalogne), Andorre, des Hètéroptères Miridae Hahn, 1831. V: 2-7. Des espéces du genre Dimorphocoris Reuter, 1891 (Halticinae, Halticini, Laboparia). - Bulletin de la Société Scientifique de Bretagne 64(1-4) (1993): 5-208.

Ehanno, B. (1997): Compléments (V-8) à la faune de France \& de pays voisins des Hétéroptères Miridae Hahn, 1831 \& contribution a l'etude du genre Dimorphocoris Reuter, 1891 (Miridae, Halticinae, Halticini, Laboparia) (Première parti).

- Bulletin de la Société Scientifique de Bretagne 66 (1995-1996): 3-88.

Fieber, F. X. (1858): Criterien zur generischen Theilung der Phytocoriden (Capsini auct.). - Wiener Entomologische Monatschrift 2: 289-327, 329-347, 388.

Gogala, A. (1994): Dimorphocoris saulii Wagner, 1965: relikt mediteranskih polpuščav v Sloveniji (Heteroptera: Miridae). - Acta entomologica slovenica 2: 13-17.

Gogala, A. (2008): Survival of the endemic Hemiptera species in Slovenia during the Holocene. In: V: Grozeva, Snejana \& Simov, Nikolaj (eds.). Advances in Heteroptera research: festschrift in honor of 80th anniversary of Michail Josifov (Pensoft series faunistica, ISSN 1312-0174, no. 82). Sofia; Moscow: Pensoft Publishers: 121-128. 
Gogala, M. (1992): Zgodba o dvoličnikih Dimorphocoris (A tale of the Dimorphocoris bugs). - Proteus 55: 59-61.

Gogala, A., Gogala, M. (1986): Seznam vrst stenic ugotovljenih v Sloveniji (Insecta: Heteroptera). - Biološki Vestnik 34: 21-52.

Gogala, M., Moder, A. (1960): Beitrag zur Kenntnis der Heteropteren-Fauna Sloweniens. - Biološki Vestnik 7: 85-99.

Heiss, E. (1984): Heteropteren aus Kreta II (Insecta: Heteroptera). - Berichte des Naturwissenschaftlich-medizinischen Vereins in Innsbruck 71: 141-155.

Joakimov, D. (1909): On the fauna of Hemiptera of Bulgaria. - Sbornik za Narodni Umotvoreniya Nauka i Knizhnina 25: 1-34. [In Bulgarian]

Josifov, M. (1961): Über drei in Bulgarien anzutreffende Miridenarten (Hemiptera, Heteroptera). - Fragmenta Balcanica 4: 21-27.

Josifov, M. (1990): Über die Verbreitung mancher Heteropterennarten auf der Balkanhalbinsel III (Insecta). - Acta Zoologica Bulgarica 40: 3-11.

Josifov, M., Simov, N. (2006): Endemism among the Heteroptera on the Balkan Peninsula. - In: Rabitsch, W. (ed.): Hug the bug - For love of true bugs. Festschrift zum 70. Geburtstag von Ernst Heiss. - Denisia 19: 879-898.

Kerzhner, I. M. (1964): New and little-known bugs (Heteroptera) from Kazakhstan and the other regions of the USSR. - Trudy Zoologicheskogo Instituta Akademiya Nauk SSSR 34: 113-130. [In Russian].

Kerzhner, I. M. (1970): New and little-known capsid bugs (Heteroptera, Miridae) from the USSR and Mongolia. - Entomological Review 49(3): 634-645. [In Russian].

Lindberg, H. (1956): Uber einige Miriden in E. de Bergevins Sammlung. - Notulae Entomologicae 36: 53-64.

Linnavuori, R. E. (1992): The lateralis group of the genus Dimorphocoris Reuter of Greece and the Middle East (Heteroptera, Miridae, Halticini). - Entomologica Fennica 3: 215-222.

Novak, P., Wagner, E. (1955): II Prilog poznavanju faune Hemiptera Dalmacije (Hemiptera - Heteroptera). - Zaštita bilja 30, Dodatak Prilozi entomofauni Jugoslavije: $1-10$.

Protić, Lj., Gogala, A., Gogala, M. (1990): Heteroptera (Insecta). In: Nonveiller, G. (ed.): The Fauna of Durmitor. Crnogorska akademija nauka i umjetnosti, Titograd, CANU Posebna izdanja 23, Odjeljenje prirodnih nauka 14: 279-313.

Rambur, J. P. (1839): Faune entomologique de l'Andalousie. Arthur Bertrand, Paris: $97-176$

Reuter, O. M. (1880): Diagnoses Hemipterorum novorum. II. - Öfversigt af Finska Vetenskaps Societetens Förhandlingar 22: 9-24 (1879).

Reuter, O. M. (1890): Adnotationes Hemipterlogicae. - Revue d'Entomologie, Caen 9: 248-254. Corrigenda 10: 27 (1891).

Reuter, O. M. (1901): Capsidae rossicae descriptae. - Öfversigt af Finska Vetenskaps Societetens Förhandlingar 45: 161-194.

Seidenstticker, G. (1957): Heteropteren aus Anatolien I. - Revue de la Faculté des Sciences de l'Université d'Istanbul 22: 179-189.

Seidenstücker, G. (1964): Über Dimorphocoris (Heteroptera, Miridae). - Reichenbachia 3(17): 209-221 
Tamanini, L. (1972): Descrizione di due nuovi Dimorphocoris montani utilizzando anche i caratteri delle armature endofalliche (Hemiptera Heteroptera Miridae). - Atti Della Societa Italiana di Scienze Naturali e del Museo Civico di Storia Naturale di Milano 113 (2): 117-132.

Tamanini L. (1982): Dimorphocoris servadeii n. sp., degli Appennini (Heteroptera, Miridae). - Memorie della Società Entomologica Italiana 60: 335-341.

Tatarnic, N. J., Cassis, G. (2012): The Halticini of the world (Insecta: Heteroptera: Miridae: Orthotylinae): generic reclassification, phylogeny, and host plant associations. - Zoological Journal of the Linnean Society 164(3): 558-658.

Vinokurov, N. N., Kanyukova, E. V. (1995): Conspect of the fauna of Heteroptera of Siberia: Contribution to the Catalogue of Palearctic Heteroptera. Yakutian Scientific Centre, Yakutsk, 62 pp. [in Russian, English summary].

Wagner, E. (1954): Eine neue Miriden-Art aus Süd-Frankreich. (Hem. Het.). Revue Francaise d'Entomologique 21: 219-222.

Wagner, E. (1965a): Über die Gattung Dimorphocoris Reuter, 1891. - Reichenbachia 5(15): 135-156.

Wagner E. (1965b): Die Gattung Dimorphocoris Reuter, 1891, II (Hem. Het. Miridae). - Reichenbachia 6(4): 33-66.

Wagner E. (1969): Über Dimorphocoris saulii E. Wagner, 1965. - Bollettino della Societa Entomologica Italiana 99/101 (3-4): 77-80.

Wagner E. (1973): Die Miridae Hahn, 1831, des Mittelmeerraurnes und der Makaronesischen Inseln (Hemiptera, Heteroptera). - Entomologishe Abhandlungen Staatl. Mus. Tierkunde Dresden, Suppl. 39(2): 1-423.

Wagner, E., Weber, H. H. (1964): Héteroptères Miridae. In: Faune de France. Vol. 67. - Paris.

\title{
DIMORPHOCORIS SAULI (HETEROPTERA: MIRIDAE), HOBA BPCTA Y ФАУНАМА СРБИЈЕ И ЦРНЕ ГОРЕ
}

\author{
ЉИљАНА ПРОТИЋ
}

\section{Р Е 3 И М Е}

Dimorphocoris saulii Wagner је нова врста стенице за фауне Србије и Црне Горе, док је род Dimorphocoris истовремено по први пут констатован за фауну Србије.

На Балканском полуострву распрострањено је девет врста рода $D i$ morphocoris: D. beieri Wagner, D. debilis debilis (Reuter), D. fuscus Joakimov, D. gracilis (Rambur), D. lateralis Reuter, D. sari Linnavuori, D. sauli Wagner, D. schmidti (Fieber) и D. tristis (Fieber). На поменутом подручју врсте насељавају Динариде (Словенија, Србија, Црна Гора, Хрватска), Родопе (Бугарска), Пинд (Грчка) и острва у Медитерану. 